\title{
Pre-service Elementary Teachers' Mathematics Content Knowledge: A Predictor of Sixth Graders' Mathematics Performance
}

\author{
Hosin Shirvani \\ Assoc. Prof., University of Texas-Pan American, Curriculum and Instruction, Edinburg, \\ Texas, USA, hshirvani@utpa.edu
}

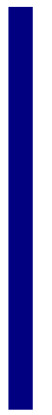

This study examined the knowledge of mathematics content of elementary preservice teachers at a sixth grade level. The researcher administered a mathematics test for sixth graders mandated by the Texas Education Agency to pre-service teachers; the same test was given to sixth graders in Texas. The study found that pre-service teachers performed lowest on objective four of the test which measures knowledge of measurement in mathematics. This performance was compared with children's scores in objective four and found that children also received the lowest score among the objectives of the test. This study implies that teachers' knowledge could affect students' performance on mathematics. The participants were 87 preservice teachers with over $90 \%$ having a Hispanic ethnic background.

Keywords: Mathematics, knowledge, performance, pre-service teachers, elementary schools

\section{INTRODUCTION}

Students in the United States do not perform well in mathematics compared with most industrial nations. A majority of students entering community colleges have to take remedial mathematics courses even though they have taken several math courses in high school (Bailey, 2009). The National Assessment of Educational Progress (NAEP) has shown that only $30 \%$ of $8^{\text {th }}$ grade students are proficient in mathematics. One reason for this performance is that that these children have not deeply learned mathematical concepts at a higher cognitive level, they just memorized them. Teachers who have deep knowledge of mathematics could better enhance students' mathematics learning (Kilpatrick et al., 2001). Moreover, when high school students were asked to find the smaller fraction when two fractions are given with the same positive numerators, but different denominators; the study showed that half of high school graduates could not answer correctly (Lindsey et al., 2012).

Most educators would agree that effective teachers will positively impact mathematics student learning. To be effective teachers, they need to have a commanding knowledge when teaching the subject matter. However, Ma (1999) found that American teachers had difficulty understanding of mathematical concepts such as division of fractions, and place number for beginner and experienced elementary mathematics teachers. Ma also found that Chinese teachers had more depth of understanding of mathematics than 
American teachers; therefore, Chinese teacher implemented more flexible strategies in teaching children to better understand complicated mathematical concepts. Furthermore, other researchers have discovered that teachers had insufficient understanding of deep mathematics when they were presented with high level mathematical problems (Ball, 1990; Ma, 1999; Simon, 1993). Research studies have also shown that many teachers lack sufficient mathematical knowledge (Hill, Schilling \& Ball, 2004). Therefore, when teachers lack the math content, they will have more difficulty presenting lesson clearly and will make more mathematical errors in the classrooms (Borko et al., 1992; Ma, 1999).

Teachers' knowledge in the subject matter is becoming increasingly important. The most recent educational act, the No Child Left Behind Act (NCLB), requires that teachers be highly qualified in their content area, and these teachers should be proficient in their subject area and must attain teaching certification in their subject areas. Moreover, The National Council of teachers of Mathematics (NCTM) (2000) states in one of its principles of learning mathematics that the emphasis should be on teachers having mathematics content knowledge in order to be effective teachers.

The purpose of this study is to examine pre-service teacher's weaknesses in the area of mathematics and its impact on students' mathematics performances of sixth graders. Therefore, this study can add knowledge to the literature by providing further evidence on a source of children' weakness in mathematical concepts.

\section{REVIEW OF LITERATURE}

What is the definition of the content knowledge? Researchers, Ball, Thames, and Phelps (2008) have defined the content knowledge required as mathematical knowledge that a teacher needs to have as a mathematics instructor. Measuring the impact of teachers' knowledge of mathematics on students' mathematics achievement is a difficult task because of interference of other variables such as teachers' experience, certification, gender, coursework (Hill et al. 2005). Moreover, there are only a few research studies that have focused on teachers' mathematics knowledge as a predictor for the students' mathematics achievement. Most researchers have used proxy variables such as teachers' number of math courses taken or college degrees as predictors for student achievement (NMPS, 2008). In this research, the investigator defines mathematics knowledge as what the Council of Teachers of Mathematics (2000) and National Mathematics Advisory Panel (2008) have recommended, which is based on the conceptual understanding of mathematics that teachers need to have in order to teach relevant mathematical concepts effectively. Therefore, the definition does not include the number of mathematics courses taken beyond high school.

\section{Content knowledge}

A study that that used actual teaches' actual knowledge, which included common and specialized mathematical knowledge, examined their effects on children's mathematics achievement is by Hill et al. (2005). That study included data from 334 first grade teachers and 365 third grade teachers, who taught 2963 students from 113 schools, found that that teachers' mathematical knowledge was strongest predictor for students' 
performance on a math test that those researchers developed. However, in this research, mathematical knowledge included both content knowledge and pedagogical knowledge (strategies teachers use). That is, pedagogical content knowledge (Shulman, 2005a). Moreover, this researcher has stated that knowledge is based on three categories: subject matter content knowledge, pedagogical content knowledge, and curricular knowledge. Subject matter knowledge is about the content knowledge and its organization in the minds of the instructor. Teachers must not only know the content, they must explain why the concept is important, and why students should know, and how it is related to other concepts. Pedagogical content knowledge is about strategies of showing and formulating content that makes it understandable to others. It also includes learning of specific content easier to understand by using different representations of ideas or concepts. Curricular knowledge refers to knowledge of different programs and corresponding materials that are used for teaching the content. It also includes how knowledge is developed across a program.

In a study, researchers (Baumert et al., 2010) evaluated both elementary teachers' mathematical content knowledge and pedagogy content knowledge on student performance and found pedagogical content knowledge was more predictive of student learning than teachers' content knowledge level. Harbison and Hanushek (1992) directly measured effects of teacher' math knowledge on student performance by administering mathematics tests to $4^{\text {th }}$ graders and their teachers. That study found that teachers with higher scores had students with higher scores - a direct correlation. However, Wilson et al. (2002), in a meta-analysis of 57 research studies did not find a direct relationship between teacher content knowledge to student achievement. Moreover, Harris and Sass (2007) discovered there were no relationships between students' performances and teachers' scores on the SAT. That is, the findings of the literature are ambiguous.

Most research studies that have focused on pedagogy of content knowledge in examining effects of teachers' mathematical knowledge on student learning. A study by Goos (2013) found that university level mathematics is beneficial to student achievement, but does not have a significant impact on students' mathematics achievement. This shows that teacher mathematical knowledge is not the only major contributor to student learning. (Goos, 2013). Barton and Sheryn (2009) reported that there are an insignificant number of research studies in finding relationship between teachers' mathematical knowledge and teaching high school mathematics effectively. However, mathematical knowledge levels of elementary mathematics teachers do have significant impact on elementary school children's mathematics teaching (Hill et al., 2005).

\section{Mathematics courses}

Rowan et al. (1997) found that there is a positive correlation between teachers' high school mathematics knowledge (common knowledge) and students' learning gains. However, a higher number of university level mathematics courses will not necessarily have a positive impact on student performance. For example, a research study by Monk (1994) showed that more than four to six courses in mathematics did not contribute to better teaching. However, Monk did find that mathematics education courses 
contributed more to student mathematics learning. Moreover, Telese (2012) argued that the number of mathematics courses taken by middle school mathematics was more related to students' performance than teachers' pedagogical knowledge. That research interestingly found that teachers with less professional development had students who outperformed children taught by teachers with more professional development in the teaching and learning of mathematics. Furthermore, research has provided evidence that teachers' scores in the subject are associated with student's performance in the subject matter being taught (Clotfelter et al., 2006). In addition, teachers' academic major is an important factor in student learning (Harri \& Sass, 2007). That is, if teachers have a passion in an area of learning and have that as a major in their university studies then there is a positive relationship to student learning as evidenced in test scores.

\section{Certification effects on content knowledge}

Researchers have found several teacher characteristics that appear to make a difference in student performance. One characteristic is for teachers to be certified in mathematics and the other one is having bachelors or master's degrees in mathematics, which is associated with higher student performance. Moreover, studies have shown that teachers, who are certified, have bachelors or master's degrees in mathematics or have teaching experience have a positive impact on student performance (Goldhaber \& Brewer, 1996). Research studies have reported also that teachers' certification or grades in the subject also positively affect performance (Ferguson 1991; Harbison \& Hanushek, 1992). Interestingly, one study found that there is a difference in mathematics achievement when teachers receive their certification from a private institution than from standard certification (Glatfelter et al., 2007). However, other researchers found that the source of certification has no significant impact on children learning (Rivkin et al., 2005; Nye et al., 2004).

Mixed findings have been reported in a number of areas in the literature on mathematics teaching and learning and so this study addresses the important area of teacher knowledge of mathematics and student learning in that area.

\section{Shirvani METHOD}

\section{Participants}

In this study 87 pre-service teachers who enrolled in the investigator's math and science methodology class participated in this research study. Participants were from a university, which is located in southern part of Texas, students' ages varied from 21 to 55 with an average age of 27, and there were 6 male and 81 female students. The researcher administered $6^{\text {th }}$ grade math tests with these pre-service teachers. In Texas, $6^{\text {th }}$ grade mathematics tests are given to all six graders in that state; the test's version was from 2011 and the name of the test was called TAKS (Texas Assessment of Knowledge and Skills). This test had a reliability of .87. The same test was given to all $6^{\text {th }}$ graders in Texas in that year. The test covered six mathematics objectives taught in Texas. These objectives are as follows: Objective 1: Number operation and quantitative reasoning, Objective 2: Patterns, Relationships, and algebratic reasoning, Objective 3: Geometry and spatial reasoning, Objective 4: Measurement, Objective 5: Probability 
and statistics, Objective 6: Mathematical process and tools. There were 45 questions on the TAKS exam.

\section{Data analysis}

Pre-service teachers' scores on the $6^{\text {th }}$ grade mathematics of Texas Assessment of Knowledge and Skills (TAKS) were calculated. The objective of the study was to examine how pre-service teachers are performing on the objectives of the test. The TAKS test obtained from the Texas Education Agency's website provide information about the six grade mathematics test which questions correspond to which mathematics objectives. So, the researcher grouped questions under six objectives after students completed the test. Then, the average scores for each mathematics objectives were computed. The scores of pre-service teachers were compared with $6^{\text {th }}$ graders' mathematics score in 2011, and 2013. When computing the average for each objective, if a student answers each objective incorrectly, a score of zero was given for it; however, for a correct answer a score of one (1) was used for the given question. That is, there were no deductions for incorrect responses.

\section{RESULTS}

The results are shown in Table 1. That data shows that pre-service teachers performed slightly better than the children, which would be reasonably expected given their more extensive experiences in mathematics. Both children and pre-service teachers did not perform well on the objective number 4, as shown in Table 1, which assesses understanding of measurement such as finding areas, volume, perimeters, etc. Table 1 shows that the pre-service teachers failed the measurement objective of the test with a score of $58 \%$ and students failed this objective with a score of $37 \%$. The result also shows that sixth graders' scores started to improve on objective 4 in 2013.

Furthermore, Table 1 shows that children performed poorly on objective 5 (probability and statistics), and teachers' scores were barely acceptable. It must be noted that results in column 4 form the Table 1 are from STAAR test for 2012-2013. In that year the name of TAKS test was changed to STAAR test and objective 6 of the exam was eliminated. The reason for this elimination is due to other states adopting five objectives, rather than six and the decision to align with that. Moreover, the NAEP test (a federally administered exam) and the National Council of Teachers of Mathematics have adopted five objectives for mathematics content. One reason for a lower performance of $6^{\text {th }}$ grade students shown in the column 4 of the Table 1 is due to the newness of the test which contained questions at higher cognitive levels than previous tests. The data on $6^{\text {th }}$ grade student results in column 3 was obtained from the Texas Education's website (2011) and the data for column 4 was obtained from the Texas Education Agency (2013). 
Table 1: Shows compares pre-service teachers' score on TAKS exam (2nd column) with 6th graders' score in Texas (columns 3 and 4)

\begin{tabular}{llll}
\hline Mathematics Objectives & $\begin{array}{l}\text { \% of correct item } \\
\text { (This study) }\end{array}$ & $\begin{array}{l}\% \text { of correct item } \\
(2010-2011)\end{array}$ & $\begin{array}{l}\% \text { of correct items } \\
(2012-2013)\end{array}$ \\
\hline $\begin{array}{l}\text { Number operation and quantitative } \\
\text { reasoning }\end{array}$ & 82 & 76 & 61 \\
\hline $\begin{array}{l}\text { Patterns, Relationships, and algebratic } \\
\text { reasoning }\end{array}$ & 85 & 70 & 62 \\
\hline $\begin{array}{l}\text { Geometry and spatial reasoning, } \\
\text { Objective 4 :Measurement }\end{array}$ & 82 & 59 & 61 \\
\hline Objective 5: Probability and statistics & 77 & 37 & 52 \\
\hline Mathematical process and tools & 81 & 48 & 59 \\
\hline
\end{tabular}

\section{DISCUSSION AND CONCLUSION}

This study investigated the performance of elementary pre-service teachers on $6^{\text {th }}$ grade mathematics TAKS, a test given to children in Texas. The study found that pre-service teachers' performed poorly on objective 4 from six mathematics objectives contained in the test. Objective 4 measures students' understanding of measurement, which includes finding areas, perimeters, angles, volume, etc. Pre-service teachers were able to achieve, on average, a score of $58 \%$, which is a failing grade. The same test was given to sixth graders in Texas. The result showed that children achieved an average score of $37 \%$, which is a very poor score. Therefore, this study suggests that given teachers of sixth graders could be weak in the area of measurement, and then university curriculum should be modified in order to help future teachers to be better prepared when teaching measurement to children. Moreover, data from the Texas Teacher Education Agency has shown that when sixth graders were tested on mathematics subject, they obtained the lowest score in the objective among six objectives, meaning children's weakest area is in the measurement. This study may further inform knowledge to the community of researchers and educators about a significant reason for children's weaknesses in mathematics in the sixth grade in Texas. In addition, a research study

Has shown that majority of high school teachers are very well qualified to teach mathematics, but that number was lower for the middle school teachers (Birman, et al., 2009). In Texas, $6^{\text {th }}$ grade level is in the middle school.

This study provides clear evidence on the importance of teachers' content knowledge in mathematics affecting school student achievement in mathematics. However, other researchers have stated that content knowledge must be considered as one of several components in relationship with other variables. Teachers need to be knowledgeable in content area, pedagogical content knowledge, and pedagogical knowledge, knowledge of students and curriculum, and other contextual knowledge.

There are several limitations associated with this study. One is that pre-service teachers' knowledge may increase as they gain more experience in teaching inn schools, so this sample may not truly represent a teacher with say ten or more years of teaching experience. Second, the researcher observed that some students did not spend sufficient time answering questions thoroughly, which could have impacted the result of the study this may or may not be significant in their resulting achievements on the test. The ethnic 
backgrounds of the participants were about $90 \%$ Hispanic, which may lack the power of generalization of the finding to teachers with other ethnic backgrounds. Therefore, while this study does contribute to this important area of pre-service teacher mathematics content knowledge and its possible relation to school student achievement in the middle years, there needs to be more studies done in this area which with teachers from other ethnic backgrounds at different grade levels.

\section{REFERENCES}

Lindsey, R., Stigler, J., \& Holyoak, K. (2012). Teaching the conceptual structure of Mathematics. Educational Psychologist, 47(3), 189-203, 2012.

Bailey, T. (2009). Challenge and opportunity: Rethinking the role and function of developmental education in community college. New Directions for Community Colleges, 145, 11-30.

Ball, D. L., Thames, M. H., \& Phelps, G. (2008). Content knowledge for teaching: What makes it special? Journal of Teacher Education, 59(5), 389-407.

Barton B., \& Sheryn, L. (2009). The mathematical needs of secondary teachers: data from three countries. Int J Math Educ Sci Technol, 40, 101-108.

Baumert, J., Kunter M., Blum, W., Brunner, M., Voss, T., Jordan A., Klusmann U., Krauss S., Neubrand, M, \& Tsai Y. (2010). Teachers' mathematical knowledge, cognitive activation in the classroom and student progress. Am Educ Res J., 47, 133180 .

Birman, B., Boyle, A., Le Floch, K., Elledge, A., Holtzman, D., Tomsen, K., \& Yoon, K.S. (2009). State and local implementation of the No Child Left Behind Act: Vol. 8. Teacher quality under NCLB: Final report. Washington, DC: U.S. Department of Education.

Borko, H., Eisenhart, M., Brown, C. A., Underhill, R. G., Jones, D., \& Agard, P. C. (1992). Learning to teach hard mathematics: Do novice teachers and their instructors give up too easily? Journal for Research in Mathematics Education, 23, 194-222.

Clotfelter, C., Ladd, H., \& Vigdor, J. (2006). Teacher-student matching and the assessment of teacher effectiveness. The Journal of human resources, 41 (4), 778-820.

Goldhaber, D \& Brewer, J (1996). Evaluating the effect of teacher degree level on Educational Performance (ERIC Number: ED406400). Grossman, P. L. (2008). Responding to our critics: From crisis to opportunity in research on teacher education. Journal of Teacher Education, 59(1), 10-23.

Goos, M. (2013). Knowledge for teaching secondary school mathematics: what counts? The effects of teacher mathematics knowledge and pedagogy on student achievement in Rural Guatemala. International Journal of Mathematical Education in Science and Technology, 44(7), 972-983. 
Harbison, R.W. \& Hanushek, E.A. (1992). Educational performance for the poor: Lessons from rural northeast Brazil. Oxford, England: Oxford University Press.

Harris, D. N., \& Sass, T. A. (2007). Teacher training, teacher quality, and student achievement. Washington DC. National center for Analysis of Longtitudinal Data in Education Research.

Hill, H., Rowan, B., \& Ball, D. (2005). Effects of Teachers' Mathematical Knowledge for Teaching on Student Achievement. Am Educ Res, 42(2) 371-406?

Hill, H. C., Schilling, S. G., \& Ball, D. L. (2004). Developing Measures of Teachers' Mathematics Knowledge for Teaching. Elementary School Journal, 105(1), 11.

Kilpatrick, J., Swafford, J., \& Findell, B., (2001). National Research Council (U.S.). Mathematics Learning Study Committee National Academy Press.

Ma, L. (1999). Knowing and teaching elementary mathematics: Teachers' understanding of fundamental mathematics in china and the United States. Lawrence Erlbaum Associates, Inc.

Monk, D. H. (1994). Subject area preparation of secondary mathematics and science teachers and student achievement. Economics of Education Review, 13, 125-145.

National Mathematics Advisory Panel (NMAP) (2008). Foundation for success: The final report of National Mathematics Advisory Panel. http://www2.ed.gov/about/bdscomm/list/mathpanel/report/final-report.pdf

National Council of Teachers of Mathematics (2000). Principles and standard for school mathematics. Reston, VA: Author.

Nye, B., Konstantopoulos, S., \& Hedges, L. (2004). How large are teacher effects? Educational Evaluation and Policy Analysis, 26 (3), 237-257.

Rivkin, S., Hanushek, E., \& Kain, J. (2005). Teachers, schools, and academic achievement Econometrica, 73 (2), 417-458.

Rowan, B., Chiang, F., Miller, J. (1997). Using research on employees' performance to study effects of teachers on students' achievement. Sociology of Education, 70 (4), 256284.

Shulman, L. (2005a). Signature pedagogies in the professions. Daedalus, 134: 3, 5259.

Shulman, L. (1987). Knowledge and teaching: foundations of the new reform. Harvard Educ Rev, 7 (57), 1-22.

Simon, M. A. (1993). Prospective elementary teachers' knowledge of division. Journal of Research in Mathematics Education, 24(3), 233-254.

Telese, J. (2012). Middle school mathematics teachers' professional development and student achievement. The Journal of Educational Research, 105, 102-111. 
Texas Education Agency (2014, April 12). Retrieved from Texas Education agency website http://www.tea.state.tx.us/student.assessment/staar/rpt/sum/yr13/.

Wilson, M., Floden, E., Ferrini-Mundy, J. (2002). Teacher preparation research: An insider's view from outside. Journal of Teacher Education 53, 190-204.

\section{Turkish Abstract}

Öğretmen Adaylarının Matematik İçerik Bilgileri: 6. Sınıf Öğrencilerinin Matematik Performanslarının Bir Yordayıcısı

$\mathrm{Bu}$ çalışma ilköğretim matematik öğretimeni adaylarının altıncı sınıf matematik konuları bilgilerini incelemeyi amaçlamaktadır. Araştırma kapsamında Texas Eğitim Bürosu tarafından altıncı sınıflar için yapılan matematik testi öğretmen adaylarına uygulanmış, aynı zamanda test Texas'taki altıncı sınıf öğrencilerine de uygulanmıştır. Çalışma bulguları testin matematikte ölçmeyi belirten bilgiyi ölçen kısmı olan 4. bölümde öğretmen adaylarının en düşük yaptığını göstermiştir. $\mathrm{Bu}$ performans öğrencilerin aynı bölümdeki puanlarıyla karşılaştırıldığında öğrencilerin de en düşük bu bölümde puan aldıkları bulunmuştur. Bu çalışma öğretmenlerin bilgilerinin öğrencilerin matematik performanslarını etkileyebileceğini göstermiştir. Katılımcılar \%90’nın üzerinde İspanyol kökenli 87 öğretmen adayından oluşmaktadır.

Anahtar Kelimeler: Matematik, Bilgi, Performans, Öğretmen adayı, İlköğretim okulu

\section{French Abstract}

Pré-entretenez la Connaissance de Contenu de Mathématiques de Professeurs des écoles : un Prophète de la Performance de Mathématiques d'Élèves de sixième

Cette étude a examiné la connaissance de contenu de mathématiques de professeurs de pré service élémentaires à un niveau de sixième(de sixième année). Le chercheur a administré un test de mathématiques sur des élèves de sixième mandatées par l'Agence d'Enseignement du Texas pour pré entretenir des professeurs; on a donné le même test aux élèves de sixième au Texas. L'étude a constaté que les professeurs de pré service ont exécuté le plus bas sur l'objectif quatre du test qui mesure la connaissance de mesure dans des mathématiques. Cette performance a été comparée avec le grand nombre d'enfant dans l'objectif quatre et trouvée que les enfants ont aussi reçu le score le plus bas parmi les objectifs du test. Cette étude implique que la connaissance des professeurs pourrait affecter la performance des étudiants sur des mathématiques. Les participants étaient 87 professeurs de pré service avec plus de $90 \%$ ayant un contexte hispanique.

Mots-clés: les Mathématiques, la Connaissance, la Performance, Pré-entretiennent des Professeurs, des Écoles Primaires 


\begin{abstract}
Arabic Abstract
العنوان: المعرفة بمحتوى الرياضيات بالنسبة لمدرسي المرحلة الإبتائية (قبل الخدمة)

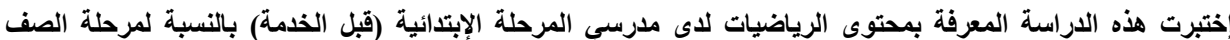

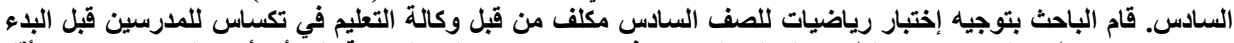

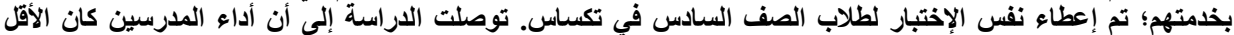

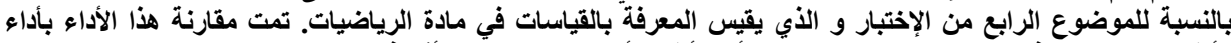

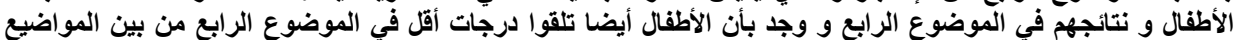

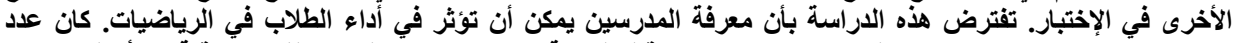

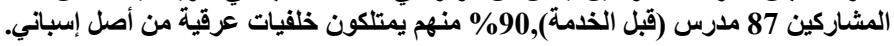

كلمات مهمة: الرياضيات,المعرفة,الأداع,المدرسين (قبل الخدمة),المدارس الإبتدائية.
\end{abstract}

